\title{
How Media Covered "Arab Spring” Movement: Comparison between the American Fox NEWS and the Middle Eastern Al Jazeera
}

\author{
Noura Alalawi* \\ PhD Student, Murray State University, USA \\ *Corresponding Contact: \\ Email: $\underline{\text { al_jenaibi@hotmail.com }}$
}

\begin{abstract}
The purpose of the research paper is the comparison of two different Media with strong political power all over the world, i.e. Fox News and Al Jazeera. The comparison will be based via a specific event; more specifically the author will investigate the way each of these media covered the Arab Spring Movement, which was initiated in Tunisia on December 17, 2010. Since this particular study is of a historical type, it will be focused on the timeline of the events and the way each media covered each of those events. In addition, the analysis section of the comparison will be based upon the actual timeline of the Arab Spring. Finally, the whole research body will be supported via the presentation of the historical background of both media, while the events themselves took place. It has to be noted that the coverage of both networks presented in the present study is based on independent sources criticizing the way this broadcasting was actually performed. The findings regarding AL Jazeera were more extensive by the ones of FOX News, always according to the research conducted on the Internet and other academic sources.
\end{abstract}

Keywords: Arab media, Fox News, Al Jazeera, Arab Spring Movement

How to Cite: Alalawi N. 2015. How Media Covered "Arab Spring” Movement: Comparison between the American Fox NEWS and the Middle Eastern AI Jazeera ABC Journal of Advanced Research, 4, 133-142.

This article is is licensed under a Creative Commons Attribution-NonCommercial 4.0 International License.

Attribution-NonCommercial (CC BY-NC) license lets others remix, tweak, and build upon work non-commercially, and although the new works must also acknowledge \& be non-commercial.

\section{INTRODUCTION}

\section{Arab Spring Movement}

Arab Spring 2010-2011 or also known as the demonstrations in the Middle East and North Africa is the revolutionary wave of demonstrations and protests that took place in the Middle East and North Africa from 18 December 2010. Prior this period, Sudan was the only Arab country that successfully overthrew dictatorial regimes in 1964 and 1985 (Al Jenaibi, 2010). During the Arab Spring uprisings occurred in Tunisia and Egypt, a civil war began in Libya, while uprisings were observed in Bahrain, Syria and Yemen. Large demonstrations happened in Algeria, Iran, Iraq, Jordan, Morocco and Oman. Smaller protests were organized in Djibouti, Kuwait, Lebanon, Mauritania, Saudi Arabia and 
Sudan. The common feature of all demonstrations was resistance through campaigns (AlJenaibi, 2008), strikes and marches and struggle via the usage of social networks such as Facebook, Twitter and YouTube aimed towards the organization, communication and information of global masses in respect the above countries efforts to stop oppression and censorship. The ultimate purpose of all demonstrators in the Arab world has been the people's desire for the regime's fall (Agrawal 2012; Mirkin 2013).

Below the reasoning of the Arab Spring during the period 2010-2011 is summarised for the countries of Tunisia, Egypt, Yemen, Libya, and Syria, while the whole duration of events is presented as a preliminary timeline. Moreover, the reasoning is presented as a means to later comprehend the actual way all these demonstrations were presented by the two different media (Rosiny 2012; Outreach Center, Center for Middle Eastern Studies 2011; Uppsala Conflict Data Program (UCDP) 2012):

- Tunisia (late 2010 - early 2011): Tunisia has been for many years presented, even in European countries as a model country in the Muslim world as it seemed characterized by financial stability and since, unlike neighbouring countries, fundamentalist Islamist organizations had no influence; however, much of the population actually lives in very poor conditions and suffers from unemployment (even recent graduates) and increasing food prices. All this combined with the corruption of the regime, the arbitrariness of the police and the violation of human rights are the real causes that led to protests and riots in late 2010 and early 2011 in Tunisia.

- From January 25 to 11 February 2011, demonstrations were escalated in many cities of Egypt with the main demand of the resignation of President Hosni Mubarak and the fight against poverty, corruption, accuracy, especially in food, unemployment and police brutality.

- In February 17, 2011 crowd gathering were observed in the capital of Bahrain in a public's decision to demonstrate against the existent monarchy, its corruption and the general problem of unemployment inside the country.

- Protests in Yemen during 2011 constitute demonstrations of Yemen's population, which followed the ones in Tunisia and Egypt. Causes of the protests are primarily unemployment, poor economic conditions and corruption. The ultimate aim of the protesters was the resignation of Ali Abdullah Saleh. The protests were initiated in mid-January.

- The revolt of 2011 in Libya was a series of riots and clashes that took place in the North African state of Libya against the government and the head of state Muammar Gaddafi.

- $\quad$ The Syrian Civil War initiated in 2011and lasting until the present day is an ongoing internal violent conflict in Syria. The insurgency has religious connotations, though no party participating to the conflicts has described sectarianism as having any important role to the war. The opposition is dominated by Sunni Muslims, while the top government officials are Alevi Muslims.

\section{Fox NEws BACKGROUND}

The TV station FOX News was established in 1996; its cofounders were Rupert Murdoch and Roger Ailes, with the concept of providing the public with more objective coverage of news and all parties' point of view presentation. Fox News reached its viewing peak during 2007, when a $20 \%$ of the American population stated that FOX News is their 
primary source of information (Conservapedia.com 2013).

More specifically, the particular TV station was formed as the other option to CNN and MSNBC; ever since 2002, when the channel's ratings surpassed those of CNN, it has been the No1 cable network in the United States (Conservapedia.com 2013).

The TV station has been accused of being in favour of the conservative party in America, a fact justified on the grounds of striving to keep its older, religious and high-income viewing group. This favouritism is said to have become apparent during the 2000 presidential elections when the channel was accused of being harsher on Al Gore and his party's representatives than on Bush, even though the same channel is responsible for revealing Bush's record of DUI. The channel's response to these accusations is that the conservatives are provided a voice in FOX News as a means of presenting the view of all parties, something that does not stand for other channels (Iml.jou.ufl.edu 2013).

\section{Al JAZEERA BACKGROUND}

Al Jazeera broadcasting was launched in 1996 at the small county of Qatar. In the beginning, the several of its employees originated from BBC; this BBC staff had in previous years started on an Arabic TV channel, which was, however, shut down due to Saudi Arabia's controller of the satellite via which this channel was broadcasted for reasons of censorship. The English version of Al Jazeera on the other hand was established 2006 and available online by the channel's website (Al-bab.com 2009).

Al Jazeera is sponsored by the government of Qatar; nonetheless, it has been provided with such editorial freedom, as never observed before in the Arab world; the result is that Al Jazeera is characterized by professionalism in terms of news coverage, while is responsible for the on-air discussion of issues formerly considered by Arab authorities and the Arabic public as forbidden or unmentionable (Al-Jenaibi, 2010). Consequently, Al Jazeera is now a media of high recognition and massive audience followers within the Arabic countries (Al-bab.com 2009).

2001 was the year when Al Jazeera received extensive interest in the western countries; it's exclusive coverage of the war in Afghanistan on a round the clock basis via a permanent satellite link a Kabul was used by a variety of different TV stations in the west. Al Jazeera also gained notorious fame since it was the broadcaster of Al-Qaida leaders' videotaped messages (Al-bab.com 2009).

The Kabul and Bagdad departments of Al Jazeera were bombed by the U.S. during the war in Afghanistan, while the Qatar head office is said to have escaped bombing due to a British minister's intervention. In spite of Bush's government opposition and aggression towards Al Jazeera, its historical importance for the endorsement of free flow news and the initiation of political discussion in the Middle East cannot be underestimated (Albab.com 2009).

\section{Coverage of Arab Spring by the Two Media}

Al Jazeera Arab Spring Coverage

The events occurring during the historical Arab Spring shifted global focus towards local television networks and certainly increased their reputation on a world basis; one of these networks was certainly Al Jazeera (English.alarabiya.net 2013). Al Jazeera's coverage of the Arabic Spring was made both in English and Arabic and was made on a 24-hour basis via its satellite television, its website, and twitter (Leight 2012). 
Contradictions in respect to the credibility of the particular network led to a series of events, such as the believed as forced resignation of its former chief, Wadah Khanfar, his substitution by Sheikh Ahmed, an administrative at Qatargas and a member of the ruling family of Qatar, the resignation of Al Jazeera's reporter, Ali Hashem, who accused the network of bias, and a general rise and fall of the network's ratings (Souaiaia, E. 2011); ratings were extremely high and $\mathrm{Al}$ Jazeera was extremely popular during the events in Egypt and Tunisia, while dropped as viewers became aware of the network's silence in Bahrain's broadcasting, the presentation of unverified videos of events in Syria, and the tame reporting of the Oman and Saudi Arabia demonstrations (Souaiaia, E. 2011; AlJenaibi, 2013). Below the coverage of different countries' participation on the Arab Spring is presented as a means of comprehending the ways Al Jazeera actually presented the whole series of events.

More specifically, during the Egyptian January 2011 demonstrations the world focused on the role of the Qatar Al Jazeera satellite network; via Al Jazeera 24-hour and real-time coverage of protests was made possible; but this coverage is suggested to have moved pass simple news presentation to becoming the representative of protestors, and the 'organizer' of the crowds coiling in the city of Cairo (other technologies, such as Facebook and twitter were also responsible for the coiling, but these were the protestors' mean and so do not interest the present study); reporters were sent to the major Egyptian cities of Cairo, Alexandria, and Suez, where the protestors' resistance to the Mubarak's power was documented and the voice of everyday Egyptian people was recorded, as a means according the network's former chief (Wadah Khanfar) of providing group gatherings with the right to be heard (Leight 2012); Wadah Khanfar also added the following: "Al Jazeera immediately after the revolution started was banned, the office was closed and correspondents were not allowed to move at all. And even the satellite signal of Al Jazeera covering Egypt was dropped from NileSat, which is the major Arab satellite distribution" (Khanfar and Kinninmont 2012).

The case of the network's broadcasting of the Tunisian demonstrations is similar to the one of Egypt (Leight 2012). Nonetheless, as stated by Khanfar, an effort was made to suppress this coverage since the Tunisian authorities managed to shut down the network's website for a long period of time (Khanfar and Kinninmont 2012).

In respect to the Libyan civil war 24-hour coverage of all riots since their outburst in February 2011, documentation of Gaddafi's violent efforts to suppress these riots and the internet's blackout as a means of deterring the rebels' coordination, presentation of the Libyan National Transitional Council, founded by forces opposing Gaddafi, and recording of the United Nations' decision of a soft powered intervention at the region were amongst the topic featured on all the networks' means of information. Nonetheless, this extensive coverage was considered the product of the influence on the network of the Qatari government's position of a clear support of the Libyan rebels (besides, as already mentioned Al Jazeera is sponsored by the government of Qatar, which can potentially manipulate the network's broadcasting choices) (Leight 2012); this political interference of Al Jazeera was denounced by Libyan leaders stating the Al Jazeera selectively broadcasted groups and people supporting the global Muslim Brethren movement and generally Libyan Muslims (Souaiaia, E. 2011).

The Al Jazeera network remained mostly silent in terms of the Bahraini revolution broadcasting. This strange silence has been explained as the result of the Qatari government's decision to avoid tension with Saudi Arabia, which has legitimate concern in Bahrain. The network's striking silence, provided space for the Qatari government's propaganda and 
misinformation unquestionably and without questioning repress the freedom of the network's coverage; thus, the Qatari's political 'alliances' seem to have overcome the network's will of unbiased coverage, and led $\mathrm{Al}$ Jazeera to the concealment of events of events potentially affecting the sensitive political transnational balance in the Middle East (Leight 2012). The deficiency of the reporting of the Bahrain events became even more apparent on the Arabic Channel of Al Jazeera's network, since its coverage would certainly have a greater political impact to the Arabic region population than to the rest Arab world population viewing the respective English Channel; as former Al Jazeera's English patron Dave Marash stated: “Al Jazeera Arabic has seriously damaged its brand in the Middle East by taking a dive on Bahrain, and basically following the dictates of the Saudi government and broadcasting only from the Bahrain royal family point of view" (Essaid and Mawad et al. 2012).

On the other hand, in respect to the Yemen revolution, the offices of Al Jazeera in Sanaa were closed down because the channel was accused of "spreading false news about the situation in Yemen". More specifically, according to the report of the Ministry of Information of Yemen, aired by the network television Saba, Al Jazeera misinformed the Arabic public when presented tortures held in Iraqi prisons as events taking place in Yemen; the Saba network informed audience that the Al Jazeera's Sanaa offices were invaded at the time by 20 armed men, who removed the network journalists' authorization of covering Yemeni events by closing down the network's local office; to sum up Al Jazeera was charged as playing a significant role in inspiring the initiation and spreading of revolution in the Yemeni ground. Nonetheless, Al Jazeera representatives contradicted above accusations by proclaiming its correspondents' daring and within difficult conditions broadcasting of the Yemeni events and further assuring its viewers that the situation in the particular country will continue being monitored in spite of its local offices' shut down (Syrian Free Press Network 2012).

The credibility of Al Jazeera was once again questioned by the Arabic population in respect to the network's coverage of the Arab Spring outspread in Syria, Eastern Saudi Arabia and Oman; though the broadcasting of events occurring in all three regions was extensive, it was accused of being cold-blooded, and as the mean of providing voice to the revolutions opposing parties via the presentation and replaying of a series of unverified videos of kidnappings, murders and military staff desertions; several of these network news' revelations were later proved to be fabricated. During these crucial events and accusations the network's at the time being chief (Wadah Khanfar) was compelled to resign, while Sheikh Ahmed took power leading by many the network's independence to subjective presentation of events, always in accordance to Qatari regime (English.alarabiya.net 2013; Souaiaia, E. 2011).

The political character of Al Jazeera is said to having become evidence once again during the November 2011initiated revolution in Syria; according to reports in respect to events of the time, when the rebels presented their suggestions to the Syrian government, its minister of foreign affairs claimed that toxic coverage termination by certain media (indirectly referring to Al Jazeera) should be included as a precondition to the rebels' suggestions (Souaiaia, E. 2011). During this time, the already mentioned resignation of Al Jazeera's reporter, Ali Hashem, took place with the rationale of the bias coverage of Bahrain's and Syria's broadcasting, and after the publication of hacked Al Jazeera's emails by the Syrian Electronic Army, where Ali Hashem's concerns of the way the network portrayed the Syrian revolution became known to the world (Global Research TV 2012). 


\section{FOX News Arab Spring Coverage}

Arab Spring also dominated the television networks in the United States during the year 2011(Al-Jenaibi, 2014); more specifically the evening news included coverage of the revolutions taking place in the different Arabic countries of an average of $10 \%$. The topcovered stories of the Arab Spring, which monopolised both foreign and domestic news of the three primary commercial networks, i.e. FOX News, CNN and MSNBC, were a) the Libyan civil war, which led to the assassination of leader Moammar Gaddafi, and b) the Egyptian demonstrations, which led to the overthrow of President Hosni Mubarak. The event occurring during the civil war in Libya and the Egyptian revolution acquired an average of 700 and 500 minutes of broadcasting on the three channels' evening news; however, the situation was not the same with the events during the Bahraini, Syrian, and Yemeni revolutions were average coverage showed a particular drop to an average of 34, 143, and 24 minutes respectively; finally, the whole Arab Spring revolution overview in respect to all different Middle Eastern and North African countries was broadcasted for a total average of 42 minutes during the year 2011 (Lobe 2012).

Nonetheless, and during the highly covered Egyptian revolution (the Muslim Brotherhood was talked approximately 847 times in 144 Fox News recordings, thus, constituting an average percentage of 5.8 times per footage (Glover 2011, 125-134)), the whole events were not presented as objectively as expected and were always commented by broadcasters, thus, influencing their opinion on the turn of events. More specifically, according to a research conducted by Glover on behalf of The Elon Journal of Undergraduate Research in Communications (2011) revealed some very interesting facts in respect to the FOX News presentation of the leading political resistance crowd, i.e. the Muslim Brotherhood; according to this particular study, and though FOX News claimed and was generally thought of being a less prejudice network with a more conservative audience than other United States' networks, it failed objectivity since: a) the explanation and frame of the Muslim Brotherhood was often associated by a language directly connected with terrorism, and Islamic extremism than was portrayed as a political movement of nonviolence and moderation; b) its coverage constantly regarded and communicated to the American public opinions that the Muslim Brotherhood constitutes a fanatic and radical organization; c) finally, the Muslim Brotherhood was depicted as menace against democracy in Egypt, thus, contradicted the general academic studies claiming the positive contribution of the Muslim Brotherhood and supporting its effect on the establishment of democracy in Egypt. As an example of such bias reporting the description of Muslim Brotherhood by Sean Hannity's (The Sean Hannity show on Fox News) is presented; according to Sean Hannity the Muslim Brotherhood is: "a real, clear present danger and the only organized political opposition. I think the odds are that radicals, maybe not immediately, but over time, they will sound moderate then it becomes radical Islamic" (Glover 2011, 125-134).

According to a survey conducted by New Jersey and presented by RNF, a website dedicated in revealing the propaganda its creators think FOX News is exercising, the New Jersey FOX News viewers seem perplexed and misinformed in respect to the Arab Spring events presentation; more specifically, the survey concluded that FOX News viewers are likely less aware of the Arab Spring's actual facts than people not watching the news at all. The survey was conducted by the Fairleigh Dickinson University with a specimen of 612 adults and asked questions regarding the Arab Spring events of 2011, such as which was their understanding and awareness of the success or failure of the Muslim Brotherhood's 
revolution and its contribution to the overthrow of Mubarak's government. The survey revealed that only a percentage of $48 \%$ of FOX News viewers managed to answer correctly to the questions asked, thus, indirectly suggesting inadequate or misinformed coverage of the Arab Spring by the particular network (RNF 2012).

Moreover, FOX News seemed to support that the Egypt's failed attempt to restore its new democracy is the result of the United States President Obama's failure in terms of foreign policy applications; more specifically, FOX News blamed Obama's government for both the Muslim Brotherhood's domination and its latter collapse; furthermore, the network's connoisseurs seemed to have negatively judge Obama's support of the Arab Spring demonstrations in general, while in the present time seem to judge Obama's presidency for exactly the opposite. This simplified presentation of the foreign politics interpretation of Obama government's handling of the Arab Spring is another reason why FOX News was accused for a bias broadcasting of the demonstrations occurring in Northern Africa and the Arabic nations during the year 2011 (Newsvine 2013).

\section{Comparison of the Two Coverages}

Based on the findings of the conducted research presented above the general conclusions is that both networks have been accused of a bias broadcasting of the events regarding the Arab Spring during the period 2010-2011. When comparing the ways this coverage was performed a lot of similarities seem to be evident. More specifically, both Al Jazeera and FOX News seem to have made an extensive coverage of the Egyptian demonstrations and the following outgrow of Mubarak and his regime. Nonetheless, the opinion expressed by the new media on this particular Arab Spring revolution is differentiated; Al Jazeera is characterised by a supportive attitude towards this revolution and is even regarded by the Egyptian population as a significant contributor of the Mubarak regime's resignation (Souaiaia, E. 2011); in contrast, FOX News took a directly opposite stance by negatively presenting the Muslim Brotherhood rebellion and presenting the particular movement as dangerous for the Egyptian democracy due to its claimed terroristic nature.

Similarly, both networks have been accused of a relatively tame and of a lower coverage extent of the totality of events referring to the Arab Spring; FOX News seems to have devoted significantly less air time to cover the Arab Spring with exception to the broadcasting to the Egyptian and Libyan revolts; Al Jazeera is even more specifically accused of broadcasting less extensively the events that took place in Bahrain, Saudi Arabia, and Oman.

On the other hand, both FOX News and Al Jazeera performed extensive coverage of the Libyan civil war; FOX News' opinion cannot be easily interpreted since this coverage varies from making negative comments of an Islamic extremist spread of the Egyptian and Tunisian revolutions to Libya, while at the same time creates notion of the rebels' heroic nature by presenting news of rebels saving trapped children at Gaddafi's hometown (Fox News 2011; Moran 2012). On the contrary, Al Jazeera has been accused of being prejudiced against Gaddafi's regime at the time the revolution was evolving.

\section{FINDINGS}

Based on all above coverage presentation and via the comparison of both networks the flowing primary findings are made:

- It is evident that both networks are accused of performing bias presentation of the events taking place during the 2010-2011 Arab Spring 
- This evidence may be trusted up to certain point, since all accusations are accompanied by supporting proof and facts; nonetheless, it has to be stressed one cannot be assured of such accusation solely based on the results of the present research; an even wider examination of the both networks coverage of Arab Spring at a potential dissertation level may be required to undoubtedly decide whether or not these networks are responsible of propaganda performances.

- $\quad$ Though both networks seem indeed prejudiced when broadcasting the Arab Spring events their expressed opinion appears to be opposite. This may be explained by the reasoning presented by Lee-Wright's study (n.d.), according to which Fox News broadcasted stories about the Arabic and Northern Africa region, obviously expressing the network's prejudiced and supportive of the Israeli stance, while AlJazeera though concurrently biased expressed events from an Arab' supportive perspective.

\section{Conclusion}

$\mathrm{Al}$ Jazeera and FOX News seem to have not objectively presented the events occurring in Northern Africa and the Arabic countries during the 2010-2011 Arab Spring. The motives hidden behind these prejudiced broadcastings are, of course, differentiated and based on the different network conditions; the FOX News opinion seems to be dictated by the network's conservative and religious audience contradicting Obama's progressive government and the non-Christian Muslim Brotherhood, while Al Jazeera seems to be driven by the Qatari government's political views and by the network's recently appointed chief, who as a member of the Qatari regime family, is reasonably supportive of this regime's opinions and interests in the region.

Nonetheless, the main conclusion is that two major television networks most possibly failed to present unbiased information regarding the events of Arab Spring, thus, leading their local public's views and beliefs towards not necessarily objectivity. Consequently, issues whether or not television networks in modern times have managed to surpass political control, ratings motives and all other factors sacrificing objective journalism still stand; should these issues be adequately addressed by television networks, the public should become more suspicious in terms of one-source news presentation, and must progress towards the investigation of multi-source information and use their rationale in order to successfully comprehend different global events and shape their own personal opinion.

\section{BIBLIOGRAPHY}

Agrawal, R. "Arab Spring: Aspirations Met or Dreams Unfulfilled?." Institute for Defense Studies and Analyses: 2012.

Al Jenaibi, B. (2010). NEW AGE OF PRESS DEMOCRACY IN THE MIDDLE EAST. ARABIC NEWS CHANNELS: AL-JAZEERA. International Journal of Academic Research, 2(4).

Al-bab.com. "Al-Jazeera television: history and background." 2009. http://www.albab.com/media/aljazeera.htm (accessed 1 Nov 2013).

Al-Jenaibi, B. (2008). The Effects of Media Campaigns on Different Cultures. Proceedings of World.

Al-Jenaibi, B. (2010). The competition between Al-Jazeera's Arab news diversity and US channels: Content analysis of Iraq war. Canadian Social Science, 6(4), 81-96. 
Al-Jenaibi, B. (2013). Satisfying Public Relations: The Promise of Social Media in the UAE, International Journal of E-Adoption, 5 (1), 1-16.

Al-Jenaibi, B. (2014). The nature of Arab public discourse: Social media and the 'Arab Spring', Journal of Applied Journalism \& Media Studies, 3 (2), 241-260.

Conservapedia.com. "Fox News Channel - Conservapedia." 2013. http://www.conservapedia.com/ Fox_News_Channel (accessed 1 Nov 2013).

English.alarabiya.net. "Battle of the airwaves as Arab Spring gives boost to TV news." 2013. http:/ / english.alarabiya.net/en/media/2013/06/09/Battle-for-the-airwaves-as-Arab-Springgives-boost-to-TV-news.html (accessed 2 Nov 2013).

Essaid, S, D Mawad and A Irrera. "Al Jazeera: One Name, Two Channels." 2012. http:/ / globalnewsroom.org/al-jazeera-one-name-two-channels/ (accessed 2 Nov 2013).

Fox News. "Libyan Revolutionary Fighters Rescue Bangladeshi Children Trapped in Sirte." 2011. http://www.foxnews.com/world/2011/10/18/libyan-revolutionary-fightersrescue-bangladeshi-children-trapped-in-sirte/ (accessed 2 Nov 2013).

Global Research TV. "Al Jazeera Journalist Resigns over Syria and Bahrain Coverage." 2011. http://tv.globalresearch.ca/2012/03/al-jazeera-journalist-resigns-over-syria-and-bahraincoverage (accessed 2 Nov 2013).

Glover, K. "Analysis of CNN and The Fox News Networks' framing of the Muslim Brotherhood during the Egyptian revolution in 2011." The Elon Journal of Undergraduate Research in Communications 2, no. 2 (2013): 125-134.

Iml.jou.ufl.edu. "FOX Bias." 2013. http://iml.jou.ufl.edu/projects/fall01/Weil/bias.htm (accessed 1 Nov 2013).

Khanfar, W and J Kinninmont. "Al Jazeera and the Arab Spring." Chatham House, 2012.

Lee-Wright, P. "News Values: An Assessment of News Priorities Through a Comparative Analysis of Arab Spring Anniversary Coverage." JOMEC Journal no. 1-19 (n.d.).

Leight, N. "Arab Spring Media Monitor: One Year of Coverage." 2012. http://uscpublicdiplomacy.org/index.php/newswire/media_monitor_reports_detail/ara b_spring_media_monitor_one_year_of_coverage/ (accessed 2 Nov 2013).

Lobe, J. "U.S.: “Arab Spring" Dominated TV Foreign News in 2011." 2012. http:/ / www.ipsnews.net/2012/01/us-arab-spring-dominated-tv-foreign-news-in-2011/ (accessed 2 Nov 2013).

Mirkin, B. "Arab Spring: Demographics in a region in transition." United Nations Development Programme. Regional Bureau for Arab States, 2013.

Moran, R. "Good News: Islamist elements rising in Libya." 2012. http://www.americanthinker.com/blog/2012/01/good_news_islamist_elements_rising_i n_libya.html (accessed 2 Nov 2013).

Newsvine. "Fox Nation vs. Reality: The Schizophrenic, Obama-Bashing, Fox News Reaction To Egypt's Quest $\quad$ For 2013. http:/ / carloz.newsvine.com/_news/2013/07/04/19288905-fox-nation-vs-reality-theschizophrenic-obama-bashing-fox-news-reaction-to-egypts-quest-for-democracy (accessed 2 Nov 2013).

Outreach Center, Center for Middle Eastern Studies. "arab spring." Harvard University, 2011.

RFN. "Really, Fox News?." 2012. http:/ / www.reallyfoxnews.com/ (accessed 2 Nov 2013).

Rosiny, S. "The Arab Spring: Triggers, Dynamics and Prospects." German Institute of Global and Area Studies, 2012. 
Souaiaia, E., A. "Qatar, Al Jazeera, and the Arab Spring." 2011. http:/ / mrzine.monthlyreview.org/2011/souaiaia171111.html (accessed 2 Nov 2013).

Syrian Free Press Network. "Al-Jazeera LOSING Credibility Everywhere - Accused of "Agenda Setting and Bias Reporting." Many are looking elsewhere for the TRUTH." 2012. http:/ / syrianfreepress.wordpress.com/2013/08/02/al-jazeera-losing-credibilityeverywhere-accused-of-agenda-setting-and-bias-reporting-many-are-looking-elsewherefor-the-truth/ (accessed 2 Nov 2013).

Uppsala Conflict Data Program (UCDP). "Timeline Arab Spring. A brief summary of key events up until December 23, 2011." UCDP, 2012. 